\title{
Impaired adipose expansion caused by liver $X$ receptor activation is associated with insulin resistance in mice fed a high-fat diet
}

\author{
Yueting Dong', Zhiye Xu1, Ziyi Zhang', Xueyao Yin'1, Xihua Lin², Hong Lí1 and \\ Fenping Zheng ${ }^{1}$ \\ 'Department of Endocrinology, Sir Run Run Shaw Hospital Affiliated with School of Zhejiang University, \\ Hangzhou, Zhejiang, People's Republic of China \\ 2Biomedical Research Center and Key Laboratory of Biotherapy of Zhejiang Province, Sir Run Run Shaw \\ Hospital Affiliated with School of Zhejiang University, Hangzhou, Zhejiang, People's Republic of China
}

Correspondence should be addressed to F Zheng

Email

zhengfenpingjindi@hotmail. com

\begin{abstract}
Liver $\mathrm{X}$ receptors (LXR) are deemed as potential drug targets for atherosclerosis, whereas a role in adipose tissue expansion and its relation to insulin sensitivity remains unclear. To assess the metabolic effects of LXR activation by the dual LXR $\alpha / \beta$ agonist T0901317, C57BL/6 mice fed a high-fat diet (HFD) were treated with T0901317 (30 mg/kg once daily by intraperitoneal injection) for 3 weeks. Differentiated 3T3-L1 adipocytes were used for analysing the effect of T0901317 on glucose uptake. The following results were obtained from this study. T0901317 reduced fat mass, accompanied by a massive fatty liver and lower serum adipokine levels in HFD mice. Increased adipocyte apoptosis was found in epididymal fat of T0901317-treated HFD mice. In addition, T0901317 treatment promoted basal lipolysis, but blunted the anti-lipolytic action of insulin. Furthermore, LXR activation antagonised PPAR $\gamma$ target genes in epididymal fat and PPAR $\gamma$-PPRE-binding activity in 3T3-L1 adipocytes. Although the glucose tolerance was comparable to that in HFD mice, the insulin response during IPGTT was significantly higher and the insulin tolerance was significantly impaired in T0901317-treated HFD mice, indicating decreased insulin sensitivity by T0901317 administration, and which was further supported by impaired insulin signalling found in epididymal fat and decreased insulin-induced glucose uptake in 3T3-L1 adipocytes by T0901317 administration. In conclusion, these findings reveal that LXR activation impairs adipose expansion by increasing adipocyte apoptosis, lipolysis and antagonising PPAR $\gamma$-mediated transcriptional activity, which contributes to decreased insulin sensitivity in whole body. The potential of LXR activation being a therapeutic target for atherosclerosis might be limited by the possibility of exacerbating insulin resistance.
\end{abstract}

(c) 2017 Society for Endocrinology Printed in Great Britain
Key Words

- liver X receptor (LXR)

- peroxisome proliferatoractivated receptor gamma (PPAR $\gamma$ )

- adipose expansion

- insulin resistance
Journal of Molecular Endocrinology (2017) 58, 141-154 


\section{Introduction}

Adipose tissue is a key regulator of energy balance, playing an active role in lipid storage and buffering and synthesising and secreting a wide range of fatty acids and adipokines into the circulation that influence systemic metabolism (Romacho et al. 2014). There is strong evidence showing that dysfunction of adipose tissue plays a critical role in the development of insulin resistance and diabetes mellitus (Abranches et al. 2015, Jankovic et al. 2015). A classical paradigm is that the more adipose tissue, the higher the prevalence of metabolic diseases, and it is this relationship that has interested researchers (Despres \& Lemieux 2006). However, recent studies have suggested that the factor linking obesity and insulin resistance may not be the absolute amount of fat accumulated but the mismatch between energy surplus and storage capacity (Lionetti et al. 2009). Allowing adipose tissue to store more lipids may prevent secondary metabolic complications caused by lipids being deposited in non-adipose organs. Thus, the ability of adipose tissue to expand and match the storage needs of energy surplus may be a key determinant in protection against the metabolic syndrome associated with obesity (Murdolo et al. 2013).

Adipose tissue mass is determined by processes governing adipocyte size and number (Hirsch \& Han 1969). The size of adipocytes increases because of increased storage of triglycerides from dietary sources or endogenous lipogenic pathways, whereas adipocyte number increases as a result of increased proliferation and differentiation (Roncari et al. 1981). Decreases in adipose tissue mass may involve the loss of lipids through lipolysis and the loss of mature fat cells through apoptosis (Alkhouri et al. 2010). Peroxisome proliferator-activated receptor $(\operatorname{PPAR} \gamma)$ is a critical regulator of adipose tissue mass. The activation of PPAR $\gamma$ leads to adipocyte differentiation and fatty acid storage (Cock et al. 2004, Medina-Gomez et al. 2007). Moreover, the expansion of adipose tissue associated with obesity may be based on a hyperplastic response of the adipose tissue regulated by $\operatorname{PPAR} \gamma$ rather than just on hypertrophy of the mature adipocytes, thus resulting in adipose tissue with smaller but more numerous adipocytes. These smaller adipocytes retain insulin sensitivity with the secretion of insulin-sensitising adipokines. This occurs in a mouse model that is heterozygous for PPAR $\gamma$, which shows improved insulin sensitivity and protection from lipotoxicity despite increased fat mass (Miles et al. 2000, Yamauchi \& Kadowaki 2001).

Liver $\mathrm{X}$ receptors (LXR), including two isoforms of $\alpha$ and $\beta$, are members of the nuclear receptor family.
Most studies of LXR have been performed in non-adipose tissue, showing a positive role of LXR in central metabolic pathway regulation including cholesterol, glucose and lipid homeostasis; however, results in recent years suggest that LXR may have important modulatory roles in adipose tissue (Nomiyama \& Bruemmer 2008, Laurencikiene \& Ryden 2012). However, studies have reported inconsistent or even contradictory results with regard to the role of LXR in regulating adipogenesis, lipogenesis and insulin sensitivity (Juvet et al. 2003, Hummasti et al. 2004). Previous reports demonstrated that LXR agonists could exhibit potent anti-diabetic effect by inhibiting hepatic gluconeogenesis, but simultaneously induce excessive triglyceride (TG) accumulation in the liver in animal models (Cao et al. 2003, Chisholm et al. 2003, Laffitte et al. 2003). It is generally believed that LXR-induced hepatic steatosis results from increased de novo lipogenesis (DNL) (Chisholm et al. 2003). However, recent study using analysis of dynamic adaptations in parameter trajectories (ADAPT) revealed that the hepatic influx of free fatty acids instead of DNL was the major contributor to hepatic TG accumulation in the early phase of LXR activation (Hijmans et al. 2015). Adipose tissue is the main source of fatty acids, it is still questionable that whether LXR activation could impair TG storage in adipose tissue and lead to ectopic fat deposition. The link between adipose tissue and liver with regard to LXR has been established by Beaven and coworkers (Beaven et al. 2013). They have shown that loss of LXR impairs hepatic lipogenesis, accompanied by a reciprocal increase in adipose lipid storage, by promoting adipose PPAR $\gamma$ pathway activity, indicating possible cross-talk between LXR and PPAR $\gamma$ in adipose tissue. Cross-talk between LXR and PPAR $\gamma$ in adipose tissue is also supported by our previous study that showed an antagonising effect of LXR on PPAR $\gamma$ in the regulation of adiponectin expression (Zheng et al. 2014).

Activation of PPAR $\gamma$ in adipose tissue by thiazolidinedione ligands promotes adipose lipid storage and secondarily increases insulin sensitivity in liver and muscle (Derosa \& Maffioli 2012). However, the role of LXR in the alteration of adipose expansion and its relation to insulin resistance has not been studied. Furthermore, whether the possible interference of the PPAR $\gamma$ pathway in adipose tissue by LXR activation results in the impairment of adipose expansion and thus impairs insulin sensitivity needs to be clarified to comprehensively understand the net outcome of the advantageous and disadvantageous effects of LXR activation.

Published by Bioscientifica Ltd. 


\section{Methods and materials}

\section{Reagents}

The dual LXR $\alpha / \beta$ agonist T0901317 was purchased from Cayman Chemical Company and pioglitazone was purchased from Sigma-Aldrich. In animal experiments, T0901317 was solubilised in a vehicle containing 3\% DMSO in PBS and administered by intraperitoneal (i.p.) injection at a dose of $30 \mathrm{mg} / \mathrm{kg}$ body weight once daily. In cellular experiments, T0901317 was prepared in a solution of 1:1 DMSO:PBS at a concentration of $1 \mathrm{mM}$, and pioglitazone was solubilised in DMSO at a concentration of $20 \mathrm{mM}$ for further dilution with cell medium.

\section{Culture and differentiation of 3T3-L1 cells}

3T3-L1 cells were purchased from the American Type Culture Collection (ATCC) and were cultured in Dulbecco's modified Eagle's medium (DMEM) containing 10\% foetal bovine serum (FBS, Bio-rad) and $100 \mathrm{IU} / \mathrm{mL}$ penicillin/ streptomycin at $37^{\circ} \mathrm{C}$ in an atmosphere of $5 \% \mathrm{CO}_{2}$ and 95\% humidity. Two days post-confluent cells (designated as Day 0) were induced to differentiate into adipocytes by the addition of differentiation mixture with DMEM containing 10\% FBS, $10 \mu \mathrm{g} / \mathrm{mL}$ insulin, $0.5 \mathrm{mM} 3$-isobutyl1-methylxanthine (IBMX) and $1 \mu \mathrm{M}$ dexamethasone. Two days later, culture medium was changed to DMEM supplemented with $10 \%$ FBS and $10 \mu \mathrm{g} / \mathrm{mL}$ insulin for 2 days. The culture medium was then replaced every other day with DMEM containing 10\% FBS for different periods until day 10.

\section{Glucose uptake analysis}

Glucose uptake activity was measured using a fluorescent D-glucose analogue 2-[N-(7-nitrobenz-2-oxa-1,3-diaz-ol4-yl)amino]-2-deoxy-D-glucose (2-NBDG, Invitrogen) in differentiated 3T3-L1 cells. Briefly, differentiated 3T3-L1 cells in 12-well plates were treated with different concentrations of T0901317 $(0,1.0$ and $10.0 \mu \mathrm{M})$ for $24 \mathrm{~h}$. Then, cells were washed with Dulbecco's phosphate buffered saline (DPBS) and incubated with $100 \mathrm{nM}$ insulin in glucose-free DMEM for $10 \mathrm{~min}$, and $60 \mu \mathrm{M} 2-\mathrm{NBDG}$ was added to the medium for another $1 \mathrm{~h}$. The medium was then washed twice with cold DPBS to remove free 2-NBDG. The cells in each well were suspended with DPBS after trypsinisation and subsequently transferred to 96 black well fluorescence plates. The fluorescence intensity of cellular 2-NBDG in each well was measured at an excitation wavelength of $485 \mathrm{~nm}$ and an emission wavelength of $535 \mathrm{~nm}$ using a fluorescent microplate reader.

\section{Electrophoretic mobility shift assay}

Differentiated 3T3-L1 cells were treated with DMSO, $10 \mu \mathrm{M}$ T0901317 and $3 \mu \mathrm{M}$ pioglitazone or co-treated with $10 \mu \mathrm{M}$ T0901317 and $3 \mu \mathrm{M}$ pioglitazone for $24 \mathrm{~h}$, and nuclear protein was extracted and quantified. Electrophoretic mobility shift assay (EMSA) was performed using doublestranded biotin-labelled oligo probes of PPRE (Beyotime Biotechnology, Haimen, China). PPAR consensus oligo sequences were as follows: 5'-CAA AAC TAG GTC AAA GGT CA-3' and 3'-GTT TTG ATC CAG TTT CCA GT-5'. PPAR-mutant oligo sequences were as follows: 5'-CAA AAC TAG CAC AAA GCA CA-3' and 3'-GTT TTG ATC GTG TTT CGT GT-5'. To investigate DNA-protein interaction, $1 \mu \mathrm{L}$ of oligo probe was incubated with nuclear extract $(20 \mu \mathrm{g})$, EMSA/gel-shift-binding buffer and nuclease-free water for $20 \mathrm{~min}$ at room temperature in a total volume of $10 \mu \mathrm{L}$. Unlabelled oligo probe was used for the cold probe competitive reaction, and unlabelled mutant oligo probe was used as the mutation probe for the cold competitive reaction. Anti-rabbit PPAR $\gamma$ antibody (Cell Signaling Technology) was added for super-shift reaction. The reaction mixture was subjected to electrophoresis $(100 \mathrm{~V}$ in $0.5 \times$ Tris-buffered EDTA solution at room temperature) using $8 \%$ nondenaturing polyacrylamide gels containing $3 \%$ glycerol, and then transferred to a positively charged nylon membrane (Beyotime Biotechnology, Haimen, China), UV cross-linked and blocked. After incubation with $5 \mu \mathrm{L}$ streptavidin-HRP conjugate, immunoreactive proteins were detected using a chemiluminescent ECL assay kit (Millipore).

\section{Animals}

All animal care procedures and methods were approved by the Animal Care Committee of Zhejiang University. Male C57BL/6 mice (aged 8 weeks) were purchased from Slack Experimental Animal Center of the Chinese Academy of Sciences (Shanghai, China). A cohort of 36 mice were housed singly and maintained on a 12-h light-darkness cycle. After 1 week of habituation fed on regular chow diet (normal diet (ND), carbohydrate, 63.92\%; protein, 26.18\%; fat, 9.9\%), animals were weighed and divided into two groups: the high-fat diet (HFD) group $(n=24)$ was fed a HFD (35\% carbohydrate, $20 \%$ protein and $45 \%$ fat) and the ND control group ( $n=12$, ND mice).
() 2017 Society for Endocrinology Printed in Great Britain
Published by Bioscientifica Ltd 
After 12 weeks, the HFD group was further randomised into two groups of 12 mice. HFD mice were treated for 3 weeks with $30 \mathrm{mg} / \mathrm{kg}$ T0901317 ( $n=12$, T0901317treated HFD mice) or the vehicle (3\% DMSO in PBS, $n=12$, HFD mice) once daily by i.p. injection. This dose has been shown to be effective in the treatment of atherosclerosis (Chen et al. 2009). The ND control group also received the same vehicle treatment by i.p. injection. Body weight was recorded once a week, and food intake was monitored every day.

\section{In vivo glucose homeostasis assays}

After 3 weeks of treatment, intraperitoneal glucose tolerance tests (IPGTT) and intraperitoneal insulin tolerance tests (ITT) were carried out. Half of the mice ( $n=5-6$ per group) were injected i.p. with glucose $(1.5 \mathrm{~g} / \mathrm{kg}$ body weight) following an overnight fast, and blood glucose levels were tested from tail blood using One Touch Ultra glucose strips (LifeScan, PA, USA) at 0 (basal), $15,30,60$ and $120 \mathrm{~min}$. Tail blood was also sampled at each time point for insulin measurements. The remaining mice ( $n=5-6$ per group) were subjected to ITT. Mice were fasted for $4 \mathrm{~h}$ prior to i.p. injection of insulin at a dose of $0.5 \mathrm{IU} / \mathrm{kg}$ body weight. Blood samples were collected from the tail at $0,15,30,60$ and $120 \mathrm{~min}$, and glucose levels were measured immediately by One Touch Ultra glucose strips (LifeScan).

After these tests followed by two-day recovery (during which period, intraperitoneal injection of T0901317/ vehicle was continued), all mice were fasted for $12 \mathrm{~h}$ and injected i.p. with saline ( $n=5-6$ per group) or insulin (10 U/kg body weight, $n=5-6$ per group) and killed $10 \mathrm{~min}$ later by cervical dislocation. Blood samples were obtained and serum was collected and stored at $-80^{\circ} \mathrm{C}$ immediately. Liver, epididymal, peri-renal and inguinal fat pads were carefully excised and weighed, and the pancreas was also dissected. After rinsing in pre-cooled PBS, part of the tissue was placed in storage tubes in a dry ice bath until the end of experiment, and then stored at $-80^{\circ} \mathrm{C}$ for later protein, RNA extraction and preparation of frozen sections and liver homogenate for triglyceride content measurements, whereas the other part was fixed in $4 \%$ formaldehyde for routine pathological staining.

\section{Blood and liver sample assays}

Serum insulin concentrations were determined using the insulin (mouse) EIA kit (Millipore). Adiponectin levels in the fasted serum were measured with the adiponectin (murine) EIA kit (Millipore). NEFA and leptin levels in the fasted serum were measured with the FFA assay kit (Cayman Chemical) and the mouse leptin ELISA kit (Millipore). Triglyceride levels in the fasting serum and liver were measured with mouse TG quantification colorimetric kit (BioVision). All kits were used according to the manufacturer's protocols.

\section{Histological analysis of adipose tissue and liver}

Adipose, liver and pancreatic tissues fixed in $4 \%$ formaldehyde were then embedded in OCT compound and cut into sections (thickness, $4 \mu \mathrm{m}$ ) according to a standard protocol. The sections were stained with hematoxylin and eosin (H\&E) and examined under a light microscope. Size of adipocytes and areas of islets were analysed using Image Pro-plus 6.0 software on H\&E staining sections. Frozen liver sections (thickness, $5 \mu \mathrm{m}$ ) were stained with Oil Red O to assess the hepatic lipid content. The extent of adipocyte apoptosis in epididymal fat was determined using a TUNEL kit (Roche Diagnostics). To quantify apoptosis, 10 visual fields at $400 \times$ from each section were analysed for TUNELpositive cells. A TUNEL index was determined using the following formula: (number of stained cells/total number of cells) $\times 100$. Immunohistochemical staining was carried out to determine insulin (rabbit anti-mouse, 1:200; Santa Cruz) levels in pancreatic tissue sections using standard protocols. An anti-rabbit horseradish peroxidase-linked secondary antibody and diaminobenzidine (Beijing Zhongshan Goldenbridge Company, Beijing, China) were used to detect specific binding for insulin, and sections were counterstained with hematoxylin. Picrosirius staining for epididymal fat sections was carried out for collagen with picrosirius red solution (picrosirius $0.4 \mathrm{~g}$ in saturated aqueous solution of picric acid $100 \mathrm{~mL}$ ) and viewed under light microscopy.

\section{Quantitative real-time RT-PCR}

Total RNA was isolated using TRIzol (Invitrogen) and reverse-transcribed with random hexamers using TaqMan reverse-transcription reagents kit (Applied Biosystems) according to the manufacturer's protocol. Real-time PCR was performed using the 7500 real-time PCR system (Applied Biosystems) and SYBR Green qPCR Kit (TaKaRa). Relative expression was normalised to that of Gapdh as an internal control for quantification of individual mRNA species and calculated using the formula http://jme.endocrinology-journals.org DOI: 10.1530/JME-16-0196
(C) 2017 Society for Endocrinology Printed in Great Britain
Published by Bioscientifica Ltd 
$2\left(-\Delta \Delta C_{t}\right)$. Primer sets were listed in Supplementary Table 1 (see section on supplementary data given at the end of this article).

\section{Western blotting}

Equal amounts of protein $(50 \mu \mathrm{g})$ denatured by boiling were separated by $10 \%$ SDS-polyacrylamide gel electrophoresis, transferred to an Immun-Blot PVDF membranes (Millipore) and blocked with 5\% non-fat milk for $1 \mathrm{~h}$ at room temperature. Membranes were then incubated with primary antibodies (diluted 1:1000) including anti-rabbit cleaved caspase 3 and 9, cleaved PARP, phosphorylated HSL (s660, s565 and s563), HSL, ATGL, perilipin (PLIN1), phosphorylated Akt, Akt, GLUT4 (plasma membrane protein) and $\beta$-actin (Cell Signaling Technology) at $4^{\circ} \mathrm{C}$ overnight. After incubation with horseradish peroxidase-conjugated goat anti-rabbit secondary antibodies at room temperature for $1 \mathrm{~h}$, immunoreactive proteins were detected using a chemiluminescent ECL assay kit (Millipore).

\section{Statistical analysis}

Data are expressed as means \pm S.E.M. (in vivo studies) or means \pm S.D. (in vitro studies). Differences between the means of individual groups were analysed with independent $t$-tests or one-way ANOVA and LSD multiple range tests. Two-way repeated measures were used for comparisons between glucose and insulin levels of IPGTT or ITT using the statistical software package SPSS 16.0. A significant difference was defined as $P<0.05$. Each in vitro experiment was conducted in triplicate.

\section{Results}

\section{LXR activation reduces fat mass accompanied by hepatomegaly and hypertriglyceridemia in mice fed a HFD}

To determine the consequence of LXR activation in obesity, C57BL/6 mice were fed a high-fat diet for 12 weeks to induce obesity and subsequently treated for 3 weeks with dual LXR $\alpha / \beta$ agonist T0901317. Figure 1A shows growth curves of C57BL/6 mice fed a high-fat diet or ND over a 15-week period. Mice fed a high-fat diet had higher body weight than those on a ND from 8 weeks (week 8: $\mathrm{ND}=26.1 \pm 0.7 \mathrm{~g} ; \mathrm{HFD}=28.5 \pm 0.6 \mathrm{~g}$; HFD + T0901317 $=28.7 \pm 0.8 \mathrm{~g}, P<0.05)$, whereas the body weight of HFD mice in the presence or absence of 3 weeks of T0901317 (30 mg/kg per day) treatment was comparable (week 15: HFD=31.4 $\pm 0.7 \mathrm{~g} ; \mathrm{HFD}+\mathrm{T} 0901317=31.0 \pm 0.8 \mathrm{~g}$, $P>0.05$, Fig. 1A). Consistent with the body weight, the food intake between them was also similar (Fig. 1B). Unexpectedly, T0901317 administration significantly decreased white fat mass including epididymal (Fig. 1C and E), peri-renal and inguinal adipose tissues (Fig. 1E) as normalised to body weight, whereas liver weight in T0901317-treated HFD mice was doubled than that of HFD mice with pale appearance (Fig. 1D and E). In the histological analysis, the adipocyte size was significantly reduced in the T0901317-treated HFD mice compared to that in HFD mice (Fig. $1 F$ and G). However, substantial lipid accumulation in the livers of T0901317-treated HFD mice was confirmed by histological staining with H\&E (Fig. 1H) and red oil (Fig. 1I), as well as the elevated triglyceride levels in the liver (Fig. 1J). The serum TG level was significantly higher (Fig. 1K), whereas adipokines of adiponectin and leptin secretion into the circulation were significantly lower in T0901317-treated HFD mice than those in HFD mice (Fig. 1L and M).

\section{LXR activation promotes adipocyte apoptosis and inflammation in epididymal fat}

To clarify whether the morphological changes in adipose tissue of T0901317-treated mice were associated with decreased cell numbers, apoptotic cells in the adipose tissue of epididymal fat were assessed. There was no difference in apoptotic nuclei numbers in epididymal fat between mice on ND and HFD with vehicle treatment; however, increased apoptosis was indicated by a 3.5-fold increase in TUNEL immunoreactivity in nuclei in epididymal fat of T0901317-treated HFD mice as compared with that in HFD mice (Fig. 2A and B). Consistently, protein levels of cleaved caspase 9, caspase 3 and PARP, typical molecules of the apoptotic pathway, were all increased by T0901317 treatment (Fig. 2C and D). Moreover, HFD elevated the expression levels of inflammatory factors including F4/80 and Mcp1 in epididymal fat, which were further exacerbated by T0901317 treatment. Additionally, administration of T0901317 increased the expressions of Tnfa and Il6 in HFD mice (Fig. 2E). Furthermore, compared with ND mice, more total collagen deposition was found in epididymal fat of HFD mice detected by picrosirius staining viewed under visible light, consistently with increased Col6a1 and Mmp2 and Mmp9 expressions. However, there was no difference in total collagen deposition or collagen gene expression levels (except Mmp2) between HFD mice with or without treatment T0901317 (Fig. 2F and G).

Published by Bioscientifica Ltd. 

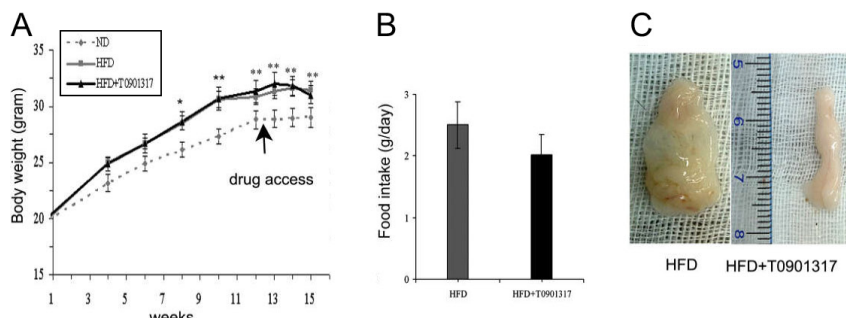

HFD HFD+T0901317
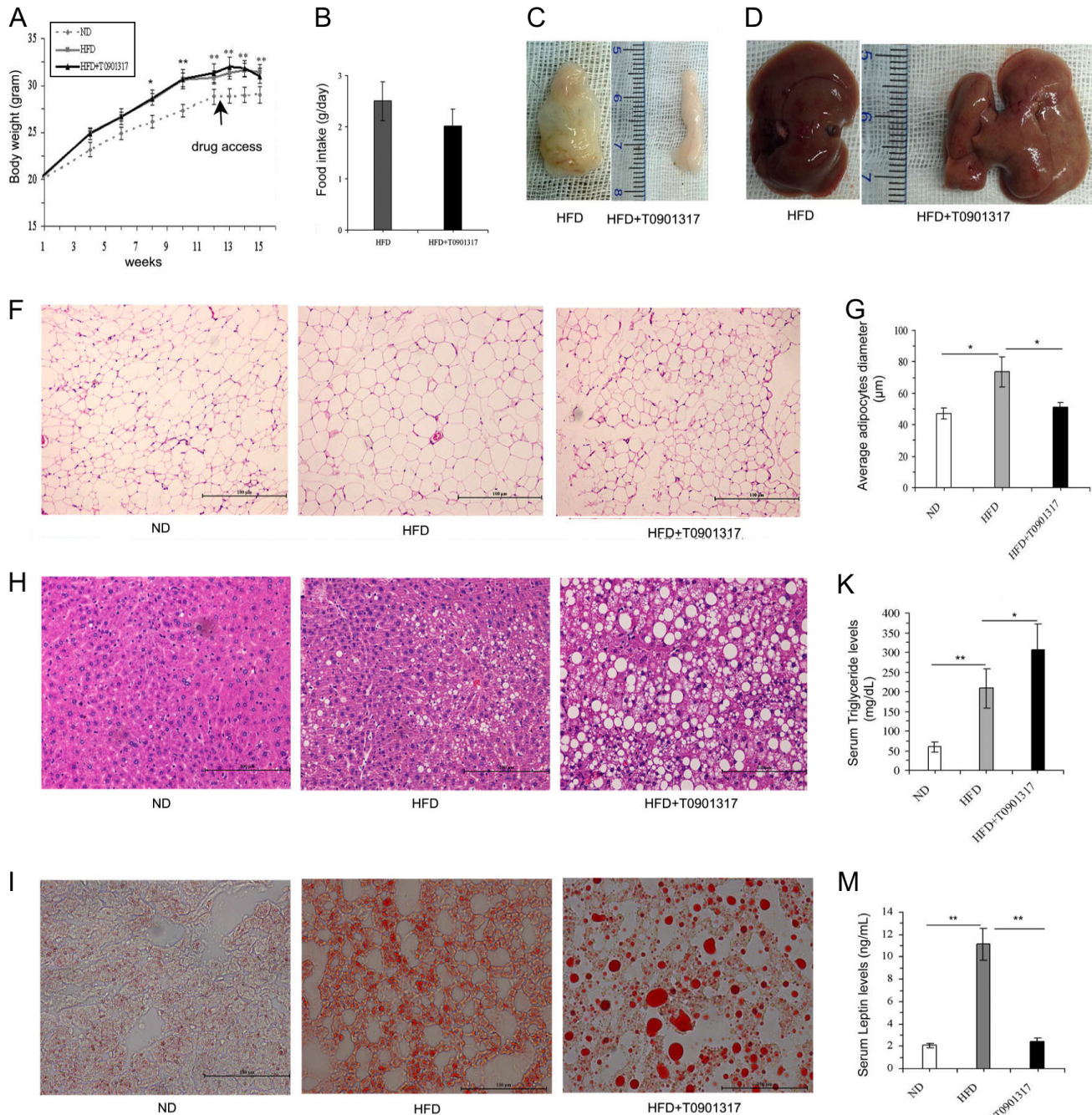
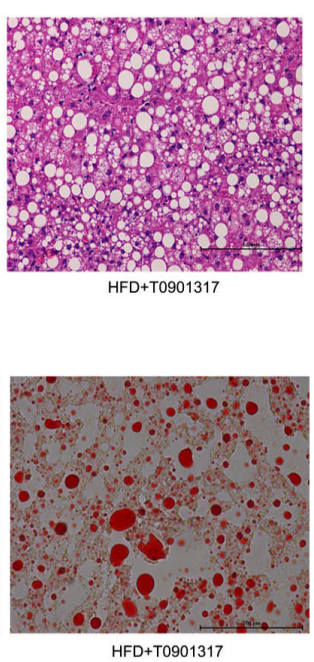

HFD+T0901317

K

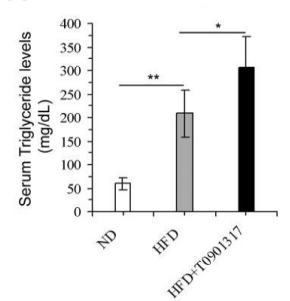

M

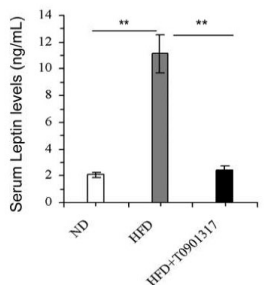

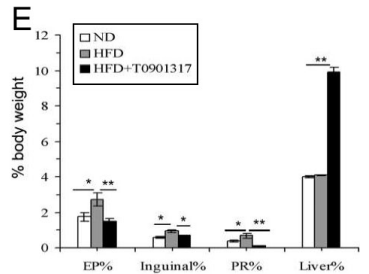

J
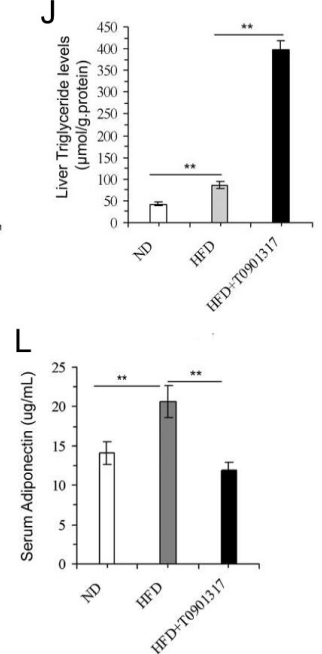

Figure 1

Characterisation of T0901317-treated mice fed a HFD. (A) Mice on ND and HFD with vehicle (HFD) or T0901317 (30 mg/kg i.p. treatment; HFD + T0901317) were weighed weekly ( $n=12$ in each group). ${ }^{*}<<0.05$ vs mice on ND. (B) Food intake in HFD mice with or without T0901317 treatment ( $n=10-12$ in each group). (C) Gross morphology of epididymal fat and (D) liver from HFD mice with or without T0901317 treatment. (E) At 15 weeks of age (3 weeks of vehicle or T0901317 treatment), mice were fasted for $12 \mathrm{~h}$, killed and organs were harvested. Weights of white fat pads (including epididymal (EP), inguinal and peri-renal (PR) adipose tissues) and liver were shown as normalised to total body weight ( $n=10-12$ in each group). (F) Representative $\mathrm{H} \& \mathrm{E}$ sections of epididymal fat from mice of different groups. Magnification $=100 \times$. (G) Average adipocyte diameter of epididymal fat from mice of different groups ( $n=8-12$ in each group). (H) Representative H\&E sections of liver from mice of different groups. Magnification=100x. (I) Representative frozen sections of liver stained with Red-Oil from mice of different groups. Magnification $=100 \times$. (J) TG levels in the liver ( $n=8-12$ in each group). (K) TG levels, (L) adiponectin levels and (M) leptin levels in serum collected from mice of different groups $(n=8-12$ in each group). Values are mean \pm S.E.M.; $* P<0.05$ and $* * P<0.01$.

\section{LXR activation increases lipolysis and inhibits PPAR $\gamma$-mediated transcriptional activity}

To demonstrate the mechanism involving the relationship between T0901317 treatment and decreased fat mass along with hyperlipidaemia, we further investigated the basal lipolysis process, as well as the insulin-induced antilipolytic action. As shown in Fig. 3A, HFD mice experienced higher fasting FFA levels in circulation than ND mice, which were further elevated by T0901317 administration.
Furthermore, after challenged with exogenous insulin, ND mice exhibited a nearly $35 \%$ drop in fasting FFA, reflecting insulin's ability to inhibit lipolysis. However, the FFA suppression to exogenous insulin was blunted in HFD mice $(P=0.076)$, which was further impaired by T0901317 administration (Fig. 3A). Perilipin1 (PLIN1), the most abundant lipid droplet-coating protein blocking basal lipolysis in adipocytes, was consistently decreased in epididymal fat of HFD mice, with the lowest level in

Published by Bioscientifica Ltd. 
A

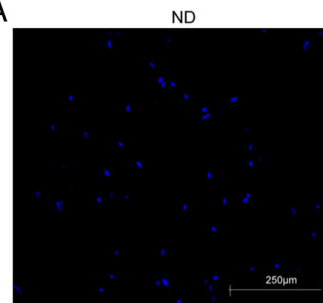

DAPI

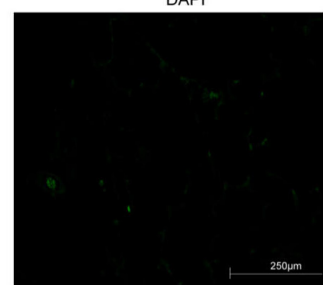

TUNEL

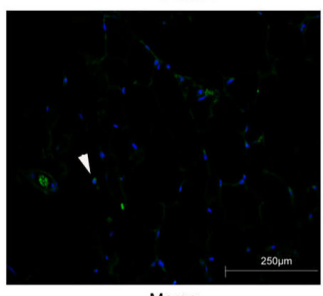

Merge

F

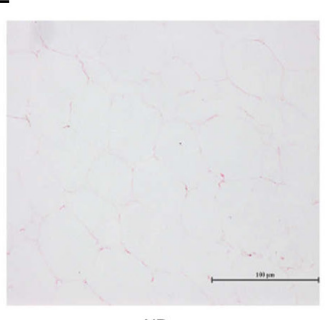

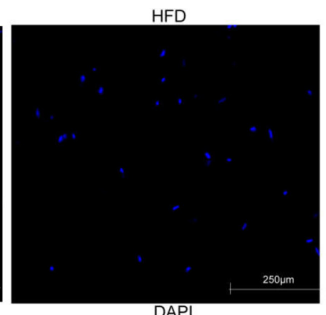

DAPI

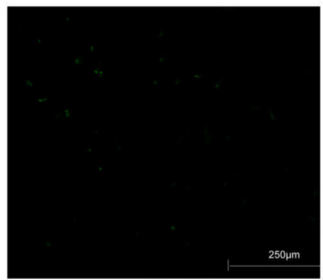

TUNEL

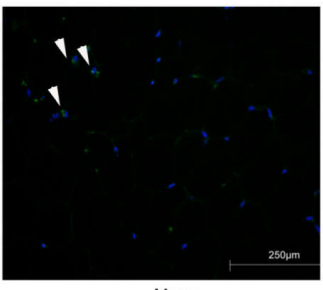

Merge

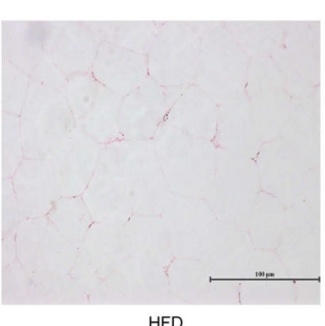

HFD+T0901317

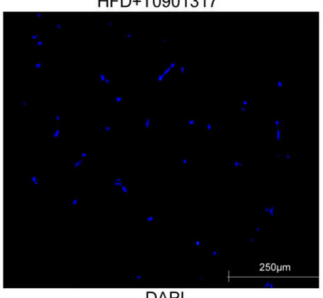

DAP

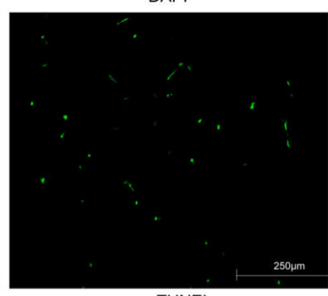

TUNEL

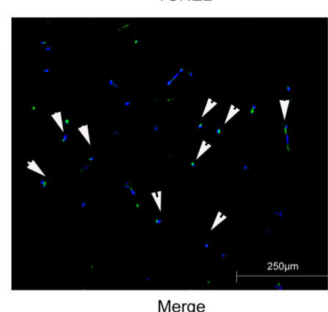

Merge

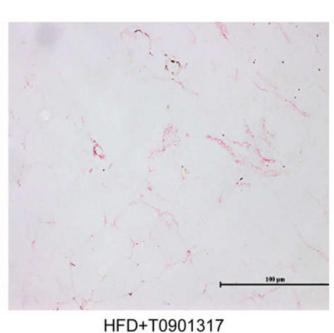

B
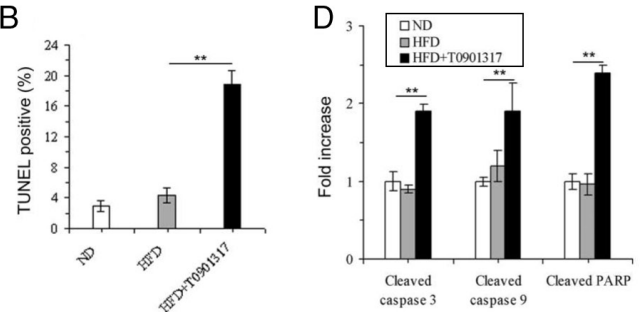

C

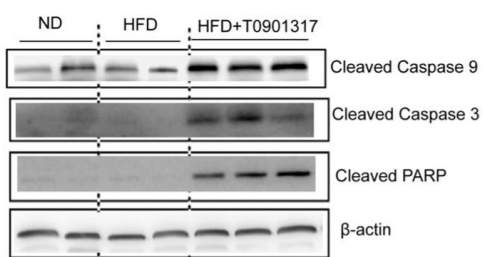

E

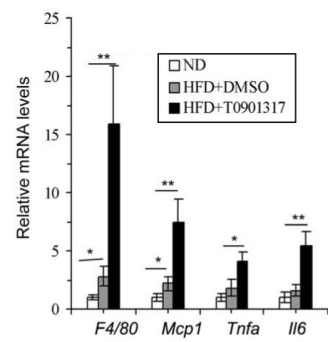

G

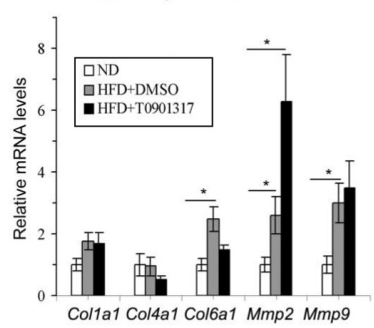

Figure 2

Adipocyte apoptosis and inflammation in T0901317-treated mice fed a HFD. (A) Epididymal fat tissue sections of mice on ND and HFD with vehicle (HFD) or T0901317 (30 mg/kg i.p. treatment; HFD + T0901317) were stained to characterise apoptotic nuclei ( $n=5-6$ in each group). Nuclei were DAPI-staining positive and apoptolic nuclei were TUNEL-staining positive. Apoptotic nuclei presented as both DAPI-staining and TUNEL-staining positive were indicated by arrows. Magnification $=400 \times$. (B) Quantification of TUNEL-positive cells in epididymal fat from mice of different groups ( $n=5-6$ in each group). (C) Protein levels of cleaved caspase-9, 3 and PARP in epididymal fat detected by Western blotting from mice of different groups. (D) Quantification of above protein levels ( $n=5-6$ in each group). (E) Quantification of the relative gene expressions of inflammatory factors by real-time PCR analysis in epididymal fat from mice of different groups ( $n=5-6$ in each group). (F) Representative picrosirius staining in epididymal fat viewed under visible light from mice of different groups. Magnification $=200 \times$. (G) Quantification of the relative gene expressions of collagen and MMPs by real-time PCR analysis in epididymal fat from mice of different groups ( $n=5-6$ in each group). Values are mean \pm s.E.M.; $* P<0.05$ and $* * P<0.01$.

T0901317-treated HFD mice (Fig. 3B and C). Insulin is known to suppress lipolysis by inactivating HSL; we thus investigated the phosphorylated forms of HSL levels in epididymal fat in HFD mice administrated with insulin. Indeed, HSL phosphorylation (s660) levels (but not s563 and s565) and its upstream protein of ATGL were significantly higher in epididymal fat of T0901317-treated HFD mice (Fig. 3D and E).

We next measured the mRNA levels of several genes involved in lipogenesis in epididymal fat. As expected,
HFD mice had higher expression levels of Srepb-1c and Fasn, instead of Ppary, Acc and Pgc-1a in epididymal fat than ND mice. Surprisingly, T0901317 treatment further induced the expressions of Srebp-1c, Fasn and Ppary without affecting $A c c$ and $P g c-1 a$ despite the fat mass reduction in HFD mice (Fig. $3 F$ ).

PPAR $\gamma$ is known to be a powerful promoter of lipogenesis and adipogenesis in adipose tissue, and it plays a critical role in adipose expansion. Regarding to the contrary pattern of PPAR $\gamma$ and fat mass reduction, we http://jme.endocrinology-journals.org DOI: 10.1530/JME-16-0196
๑ 2017 Society for Endocrinology Printed in Great Britain 

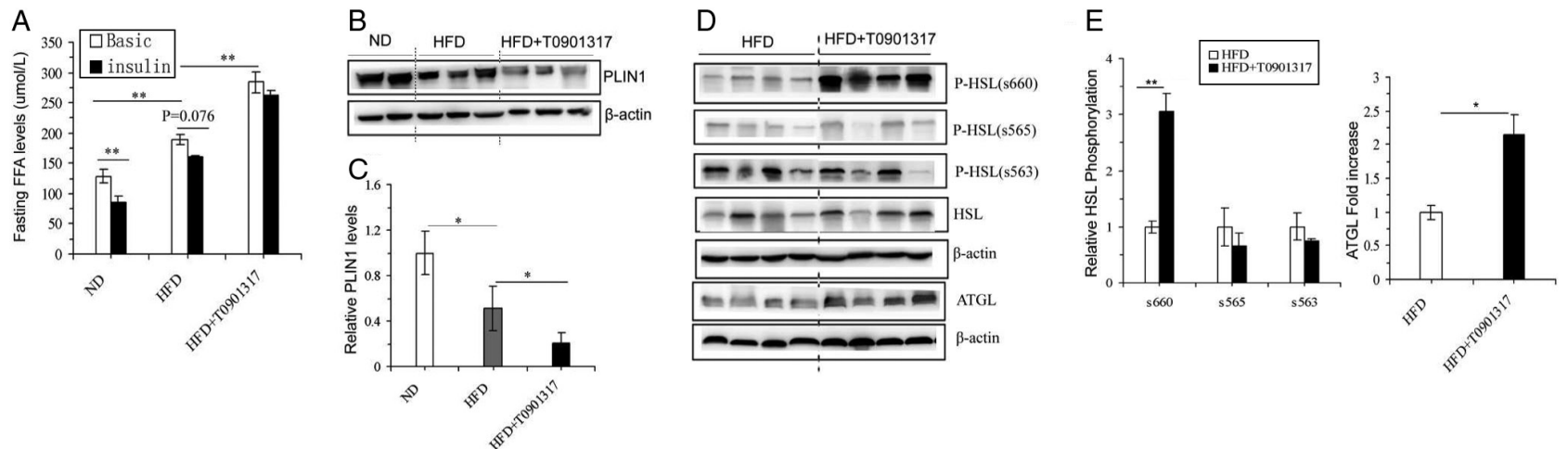

F

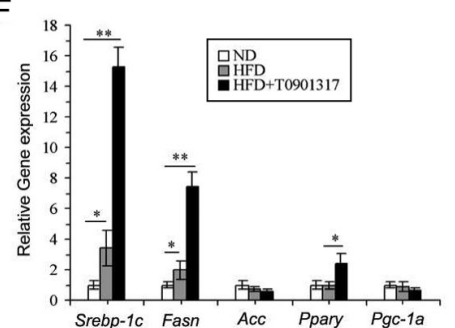

G

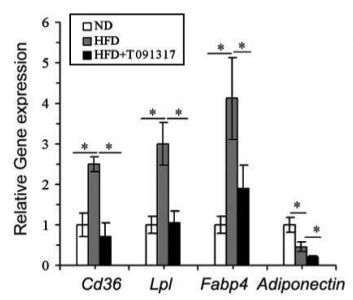

$\mathrm{H}$

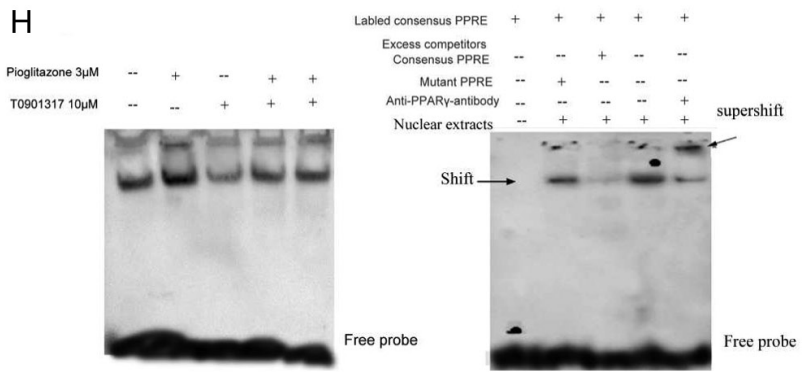

Figure 3

Lipolysis in T0901317-treated mice fed a HFD and the effect of LXR on PPAR 7 transcriptional activity. (A) Serum FFA levels in mice on ND and HFD with vehicle (HFD) or T0901317 (30 mg/kg i.p. treatment; HFD + T0901317) after $10 \mathrm{~min}$ of saline (as basic) or insulin (10IU/kg i.p.) injection before killing ( $n=5-6$ in each group). (B) Protein levels of PLIN1 in epididymal fat detected by Western blotting from mice of different groups. (C) Quantification of PLIN1 protein levels ( $n=4$ in each group). (D) Lipolytic proteins of ATGL and phosphorylation forms of HSL detected by Western blotting from epididymal fat extracts of mice pre-treated with insulin before killing. (E) Quantification of ATGL and relative phosphorylated HSL levels ( $n=4$ in each group). (F) Quantification of the relative expressions of lipogenic genes by real-time PCR analysis in epididymal fat from mice of different groups ( $n=5-6$ in each group). (G) Quantification of the relative expressions of PPAR $\gamma$ target genes by real-time PCR analysis in epididymal fat from mice of different groups ( $n=5-6$ in each group). (H) The binding of PPAR $\gamma$ to PPRE in the presence or absence of pioglitazone or T0901317 in differentiated 3T3-L1 adipocytes in EMSA analysis. Values are mean \pm S.E.M., ${ }^{*} P<0.05$ and $* * P<0.01$.

next investigated the effect of T0901317 administration on PPAR $\gamma$ target genes. As shown in Fig. 3G, HFD mice had elevated expression levels of PPAR $\gamma$ typical target genes, including the lipogenic genes of Fabp4, Lpl (the gene responsible for hydrolysis of lipoproteinbound triglycerides supplying fatty acids and glycerol to adipose depot) and Cd36 (the gene responsible for fatty acid transport to adipose tissue), but had reduced expression of the insulin-sensing gene of adiponectin in epididymal fat compared with ND mice .Surprisingly, all the previously mentioned PPAR $\gamma$ target genes were decreased by T0901317 treatment in HFD mice, suggesting an antagonising effect of LXR on the PPAR $\gamma$ mediated transcriptional activity, and this finding was supported by in vitro studies. Figure $3 \mathrm{H}$ showed that the binding of PPAR $\gamma$ to PPRE was increased with PPAR $\gamma$ agonist of pioglitazone treatment, whereas T0901317 treatment decreased the activity in the presence or absence of pioglitazone in 3T3-L1 adipocytes analysed by electrophoretic mobility shift assays (EMSA).

\section{LXR activation induces lipid accumulation in the liver}

Generally, increased lipolysis and FFA secretion from adipose tissue lead to ectopic fat accumulation, which was indeed found in T0901317-treated HFD mice showing enlarged liver and lipid accumulation (Fig. 1D, H and I). Consistent with lipid deposition, the lipogenic genes of Srebp-1c and Fasn in the liver were significantly increased in T0901317-treated HFD mice. In contrast to epididymal fat, the $L p l$ gene, responsible for hydrolysis of lipoproteinbound triglycerides supplying fatty acids for liver, was significantly induced by T0901317 administration in HFD mice. By contrast, $C d 36$, the gene for fatty acid transport, was not changed by T0901317 treatment (Fig. 4A), suggesting that a decreased fatty acid influx in adipose tissue might facilitate more fatty acid flow to the liver resulting in triglyceride synthesis. Furthermore, the genes responsible for fatty acid oxidation including Cpt1a and Ppara were decreased, supporting lipid deposition in the liver (Fig. 4B).

Published by Bioscientifica Ltd. 

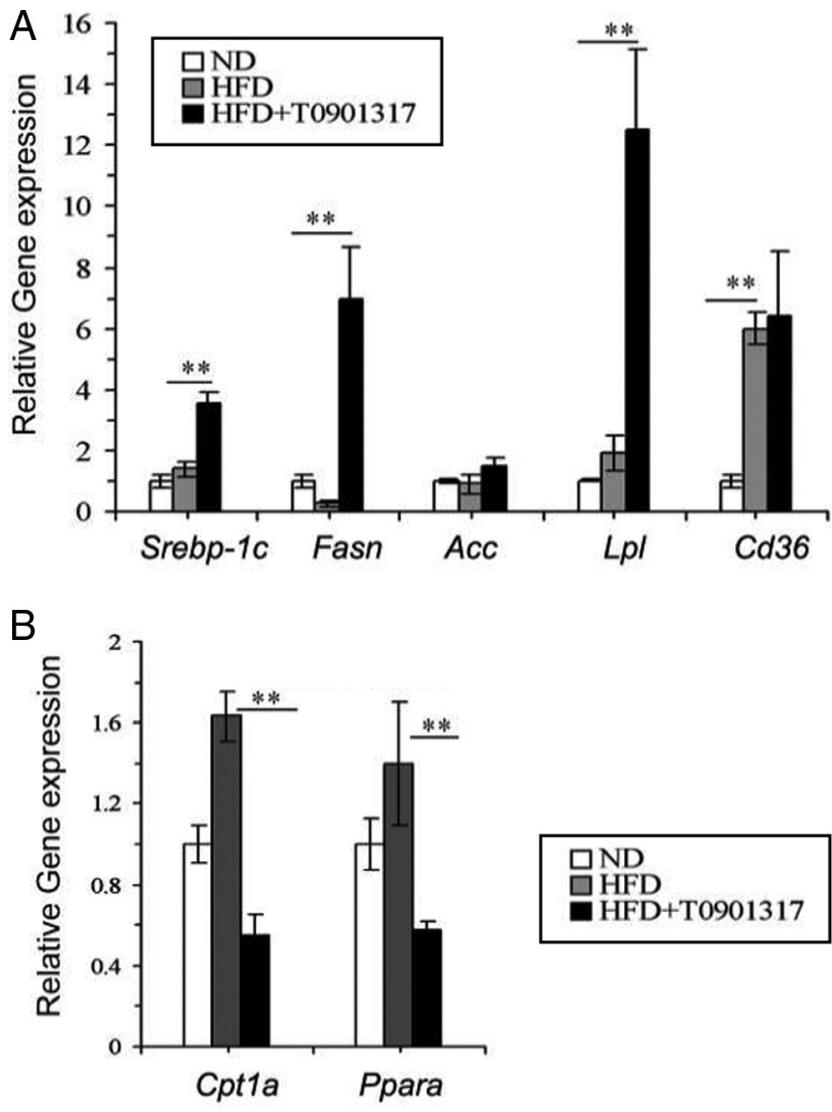

Figure 4

Lipid deposition-related genes in the liver of T0901317-treated mice fed a HFD. (A) Quantification of the relative expressions of lipogenic genes by real-time PCR analysis in liver from mice of different groups ( $n=5-6$ in each group). (B) Quantification of the relative expression of fatty acid oxidative genes by real-time PCR analysis in liver from mice of different groups ( $n=5-6$ in each group). Values are mean \pm s.E.M., ${ }^{*} P<0.05$ and $* * P<0.01$.

\section{LXR activation induces insulin resistance in epididymal fat and in the whole body}

The change of morphology and metabolism of adipose tissue is usually associated with impaired glucose utilisation in adipose tissue, leading to impaired glucose homeostasis in the whole body; therefore, we studied whether LXR affected the glucose response and insulin sensitivity in T0901317-treated HFD mice.

Fifteen weeks of HFD successfully induced diabetes and insulin resistance in C57BL/6 mice; these mice showed a significantly higher glucose and insulin response in IPGTT than mice on ND (Fig. 5A, B, C and D). Although the glucose response was comparable in IPGTT between HFD and T0901317-treated HFD mice (Fig. 5A and B), the insulin response of T0901317-treated HFD mice was significantly higher than that of HFD mice, implicating a decrease in insulin sensitivity with T0901317 treatment
(Fig. 5C and D). The decreased insulin function was further confirmed by ITT. As shown in Fig. 5E and F, the area under the curve of glucose was significantly higher in T0901317-treated HFD mice after insulin overloading, indicating decreased whole-body insulin action by LXR activation.

To further clarify the effect of LXR on glucose uptake in adipose tissue, we studied the glucose utilisation in vitro. In differentiated 3T3-L1 adipocytes, both 1 and $10 \mu \mathrm{M}$ T0901317 treatments decreased basal glucose uptake, as well as diminished the glucose uptake increase stimulated by exogenous $100 \mathrm{nM}$ insulin (Fig. 5G).

In accord with these results, the typical markers of insulin signalling activity, Akt phosphorylation and GLUT4 protein translocation to the membrane after insulin loading were markedly decreased in epididymal fat of T0901317-treated HFD mice (Fig. 5H and I). Consistent with increased insulin levels, histological analysis revealed enlarged and an increased number of pancreatic islets, as well as larger areas of islets in T0901317-treated HFD mice (Fig. 5J, K and L).

\section{Discussion}

The present study demonstrates that LXR activation causes a reduction in adipose tissue mass but results in massive fatty livers, accompanied by increased adipocyte apoptosis and lipolysis, as well as decreased PPAR $\gamma$ mediated transcriptional activity in adipose tissue. Moreover, impaired adipose expansion by LXR activation is associated with decreased insulin signalling in adipose tissue and decreased insulin sensitivity of the whole body in HFD-fed mice.

Consistent with the findings of Beaven and coworkers and Korach-André and coworkers (Korach-Andre et al. 2011, Beaven et al. 2013) who described that global LXR deletion in the setting of obesity shifts the programme of de novo lipogenesis from the liver to adipose tissue, we found an opposite phenotype, showing that LXR activation caused reductions in fat pads but liver enlargement and fatty steatosis. Loss of adipocytes through apoptosis by LXR activation might be an important process leading to fat mass reduction in the present study. Apoptosis of adipose tissue is relatively poorly studied compared to that in other tissues; yet, increased adipocyte apoptosis has been recently proposed to contribute to obesity and to differences in regional fat distribution or expansion and insulin resistance, in both obese animals and humans (Alkhouri et al. 2010, Tinahones et al. 2013, Bennett et al. 2014). As shown in the present study and others

Published by Bioscientifica Ltd 
A

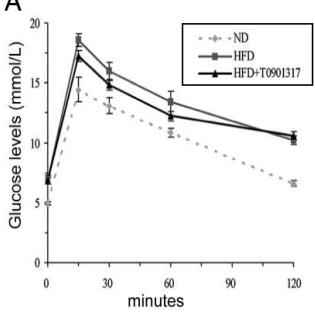

B

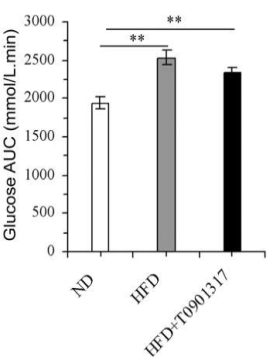

F

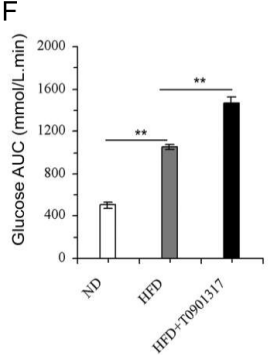

J
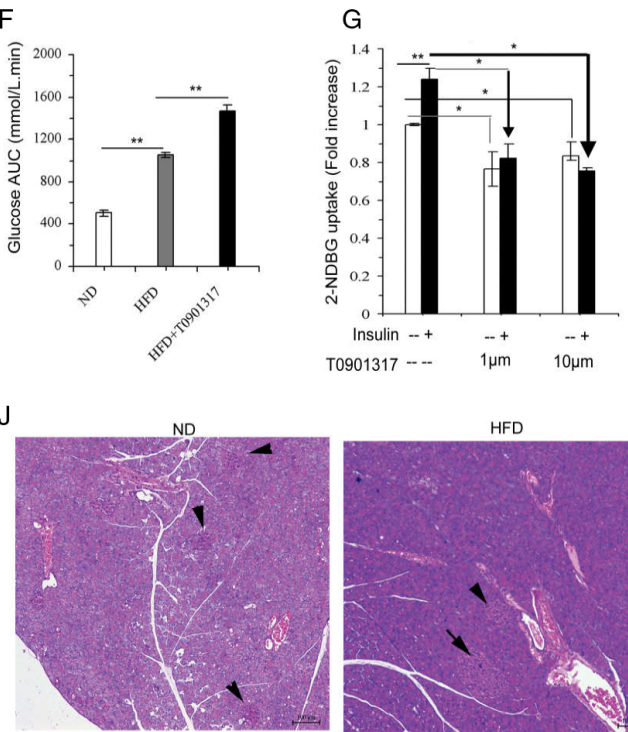

$\mathrm{H}$

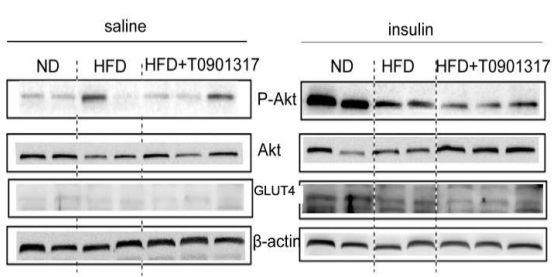

C

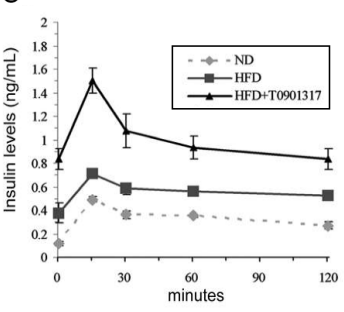

D

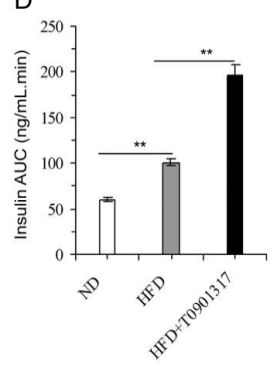

E

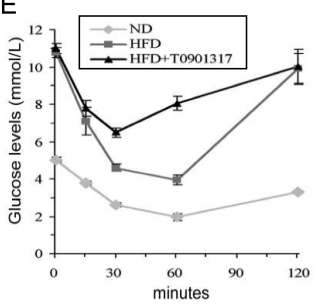

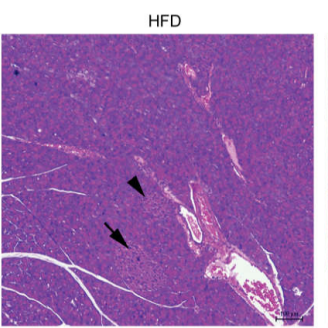
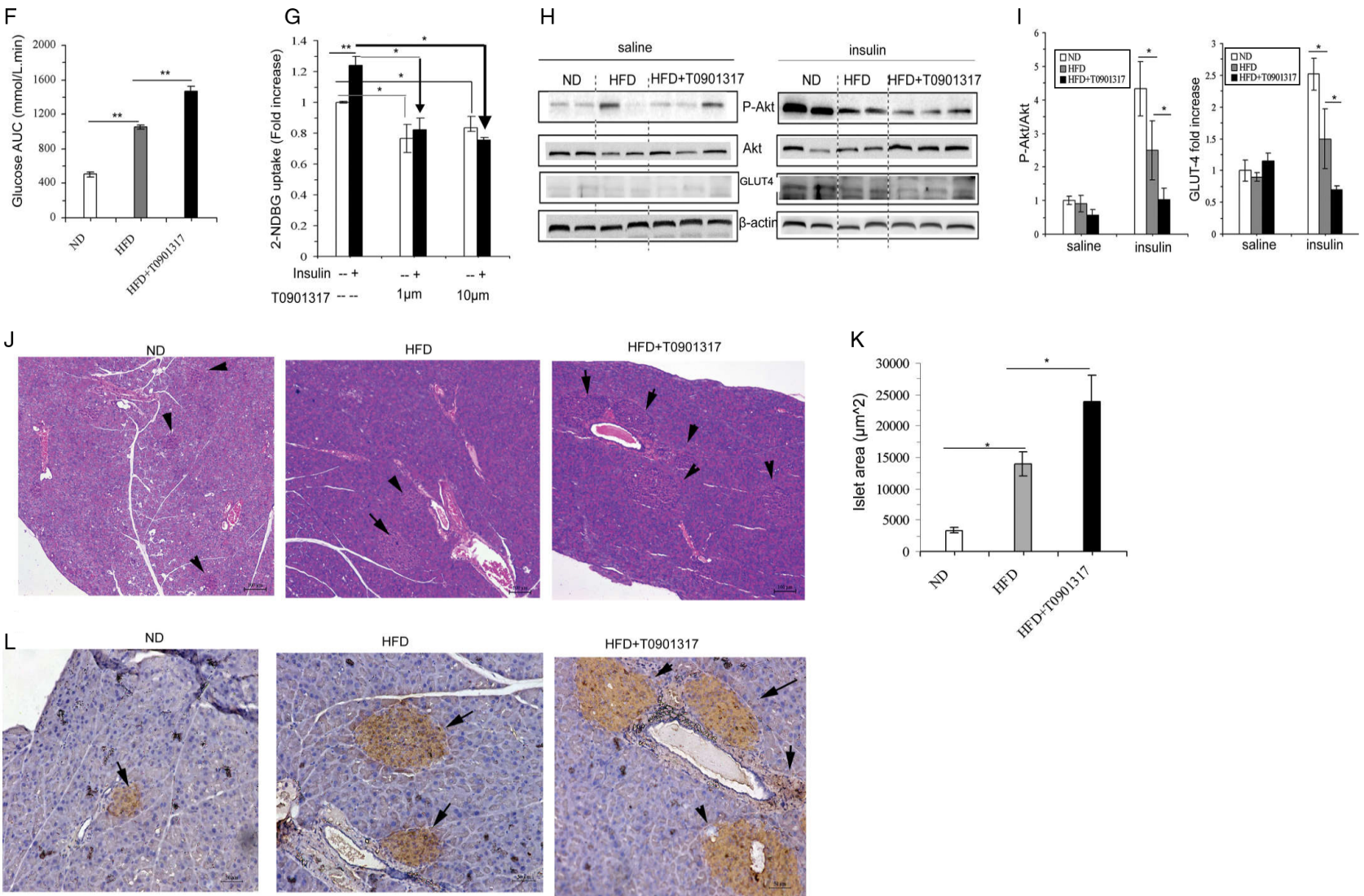

Figure 5

T0901317-treated HFD mice are glucose tolerant but insulin resistant. (A) Glucose responses in IPGTT and (B) glucose area under the curve in IPGTT of mice on ND and HFD with vehicle or T0901317 administration after overnight fast ( $n=5-6$ in each group). (C) Time course measurements of insulin from the same IPGTT and (D) insulin area under the curve in IPGTT ( $n=5-6$ in each group). (E) Glucose responses in ITT and (F) glucose area under the curve in ITT in mice from different groups after fasted for $4 \mathrm{~h}$ ( $n=5-6$ in each group). (G) Differentiated 3T3-L1 was treated by different doses of T0901317 in the presence or absence of $100 \mathrm{nM}$ insulin, and basal and insulin-stimulated 2-NDBG uptake were measured. Fluorescence intensity of 2-NBDG was recorded by absorbance measurements. Values are shown as mean \pm S.D., $n=3$ C. (H) Phosphorylation of Akt and membrane GLUT-4 translocation were detected by Western blotting from mice of different groups pre-treated with saline or insulin before killing. (I) Quantification of relative above protein levels ( $n=4$ in each group). (J) Representative H\&E sections of pancreatic islets from mice of different groups. Magnification $=200 x$. (K) Quantification of the relative islet areas in mice of different groups ( $n=5-6$ in each group). (L) Representative immunohistochemistry sections of insulin-positive pancreatic islet staining from mice of different groups. Magnification $=200 x$.

(Alkhouri et al. 2010, Tinahones et al. 2013, Bennett et al. 2014), increased adipocyte apoptosis usually results in macrophage infiltration and inflammation, which are associated with insulin resistance. Furthermore, insulin resistance induced by inflammatory factors is reversed by interference with apoptosis initiation via CASP3/7 inhibition.

Lipid storage is determined by the balance between fat synthesis (lipogenesis) and fat breakdown (lipolysis/ fatty acid oxidation). Lipogenesis encompasses the http://jme.endocrinology-journals.org DOI: 10.1530/JME-16-0196
C 2017 Society for Endocrinology Printed in Great Britain
Published by Bioscientifica Ltd 
processes of fatty acid synthesis and triglyceride synthesis and takes place in both the liver and adipose tissue, and it is the crucial process for adipose expansion. Although LXR agonists are well-characterised inducers of hepatic lipogenesis via SREBP-1c and its response genes FASN, ACC and SCD1 (Schultz et al. 2000, Yoshikawa et al. 2001), we did not find a role of LXR activation in lipogenesis in adipocytes, although significantly increased expression of Srebp-1c and Fasn were found in epididymal fat. This finding is supported by Archer and coworkers (Archer et al. 2013) who showed increased SREBP-1c expression in visceral fat but lower visceral fat mass. These results suggest that at least in rodent adipose tissue, LXR and SREBP-1c are not the primary regulator of lipogenesis; this conclusion is supported by data from SREBP- $1 \mathrm{c}^{-/-}$mice and mature adipocytes isolated from $\mathrm{LXR} \alpha / \beta^{-/-}$mice, both of which showed a similar level of lipogenesis to that in their wildtype littermates (Kalaany et al. 2005).

However, increased basal lipolysis supported by increased fasting FFA levels in the circulation by T0901317 treatment might contribute to reduced adipocyte size and fat mass by LXR activation. Similar treatment with GW3965 resulted in smaller fat cells (Archer et al. 2013), indicative of increased triglyceride utilisation. An effect of LXR on basal lipolysis is also supported by findings in human adipocytes and adipose tissue LXRo-knockout (ATaKO) mice (Stenson et al. 2011, Dib et al. 2014). Downregulation of lipid droplet-coating proteins of PLIN1, as found in our present study might be the molecular mechanism, for low levels or absence of PLIN1, has been implicated in enhanced spontaneous lipolysis both in mice and humans (Martinez-Botas et al. 2000, Tansey et al. 2001, Mottagui-Tabar et al. 2003). In addition, we found that the insulin-induced anti-lipolytic action was significantly blunted by LXR activation. Insulin is known to suppress lipolysis by inactivating HSL (Choi et al. 2010). In T0901317-treated HFD mice, we did find HSL phosphorylation and its upstream molecular of ATGL were higher than those in vehicle-treated HFD mice with same dose of insulin administration, supporting the reduction of fat mass was associated with lipolysis. Furthermore, the expression levels of Cd36 and Lpl (proteins involved in lipid clearance from the circulation and deposition in adipose tissue as triglycerides) were decreased, which might contribute to increased TG and FFA levels in the circulation and decreased fat mass in T0901317-treated HFD mice. PPAR $\gamma$ is critically required for adipose tissue expansion by increasing lipogenesis and adipocyte proliferation. Indeed, consistent with reductions in fat mass and increases in adipocyte apoptosis, we found that PPAR $\gamma$-mediated transcriptional activity was inhibited by LXR, which was supported by the reduced PPAR $\gamma$-PPRE binding activity in T0901317treated 3T3-L1 cell, as well as the inhibited PPAR $\gamma$ target genes expression in epididymal fat in T0901317-treated HFD mice. Although the mechanism of LXR interfering with the PPAR $\gamma$ pathway was not further studied, the fact that LXR shares its heterodimerising partner (that is RXR) with PPARs and sometimes competes for the same DNA response elements suggests that LXR could affect PPAR signalling (Ide et al. 2003, Yoshikawa et al. 2003).

Impaired adipose expansion was generally associated with ectopic lipid accumulation and insulin resistance. Indeed in the present study, moderate hepatomegaly and steatosis, as well as higher insulin levels, decreased insulin sensitivity and enlarged pancreatic islets were consistent with other animal models of impaired adipose expansion and human lipoatrophy or lipodystrophy (Garg 2011, Wang et al. 2013). The role of LXR activation in fatty acid synthesis in the liver is well established (Cha \& Repa 2007, Baranowski 2008). Indeed, our study also found that typical genes of lipogenesis, including Srebp-1c and Fasn, were significantly induced by T0901317 administration. Importantly, we further found increased $L p l$ and decreased Ctp1a and Ppara in the liver, suggesting an increased capacity of fatty acid intake and decreased fatty acid oxidation in the liver, which might also be another mechanism for hepatic steatosis by LXR activation. It is worth pointing out that pancreatic islets in T0901317treated mice generated double the insulin levels, which at least suggests insulin resistance instead of a direct stimulating effect of LXR activation, for blood glucose responses in T0901317-treated mice were comparable instead of lower than those in HFD mice, and this finding was supported by ITT results which showed that T0901317-treated mice had a blunted glucose response to exogenous insulin. Decreased insulin efficiency was most likely associated with increased FFA levels and decreased levels of the insulin-sensitising adipokines of adiponectin and leptin.

Glucose uptake in adipose tissue influences wholebody glucose homeostasis. The effect of T0901317 on glucose utilisation in adipocyte is not consistent (Laffitte et al. 2003, Stenson et al. 2009, Pettersson et al. 2013). In our study, we found that T0901317 decreased both basal and insulin-stimulated glucose uptake in 3T3-L1 cells. Decreased glucose uptake in adipose tissue was supported by insulin-induced Akt activity and GLUT4 membrane http://jme.endocrinology-journals.org DOI: 10.1530/JME-16-0196
() 2017 Society for Endocrinology Printed in Great Britain
Published by Bioscientifica Ltd 
translocation in T0901317-treated mice. This result is consistent with the in vitro findings of other studies either using the same cell model or primary human adipocytes (Stenson et al. 2009, Pettersson et al. 2013). Although other studies have shown unchanged or increased basal glucose uptake, the discrepancies between these studies could result from differences in agonists, in vitro cell models and treatment conditions. Despite decreased glucose uptake in adipocytes, whole-body glucose homeostasis was not changed in T0901317-treated mice. This finding probably resulted from the compensatory increase in insulin secretion and pancreatic islet enlargement. The relatively stable glucose metabolism might also be due to decreased gluconeogenesis by LXR activation (Laffitte et al. 2003, Liu et al. 2006, Commerford et al. 2007). A few studies addressing the role of LXR in carbohydrate metabolism have shown improved glucose tolerance by LXR activation in vivo; however, no study has investigated the fat mass change. No change of systemic glucose homeostasis was shown in ob/ob female mice with T0901317 treatment in the study by Archer and coworkers, in which they also found decreased visceral fat mass with GW3965 treatment (Archer et al. 2013). Thus, the adipose tissue loss in these studies might be the reason for the discrepancies. Decreased adipose mass is possibly only caused by a relatively higher dose or longer treatment period, as in our study and the study by Archer and coworkers.

The ability of LXR agonists to promote reverse cholesterol transport and inhibit inflammatory response in macrophages makes them extremely attractive therapeutic targets in human metabolic diseases (Zelcer \& Tontonoz 2006). However, administration of LXR agonists to mice induces lipogenesis in the liver and raises plasma triglyceride levels (Chisholm et al. 2003). In particular, we suggest that LXR activation can impair adaptive adipose expansion, lead to ectopic lipid deposition in the liver and worsen insulin resistance under the metabolic condition of relative energy surplus. Our data suggest that the comprehensive effect of LXR activation on metabolism may attribute to its influences on many organs, particularly the adipose tissue and the liver. The anti-diabetic and anti-atherosclerotic effects of LXR activation will likely be limited unless their effects on adipose expansion and lipogenetic process in liver can be pharmacologically separated from the effects on glucose metabolism and inflammatory response.

\section{Supplementary data}

This is linked to the online version of the paper at http://dx.doi.org/10.1530/ JME-16-0196.
Declaration of interest

The authors declare that there is no conflict of interest that could be perceived as prejudicing the impartiality of the research reported.

\section{Funding}

This work was supported by the National Natural Science Foundation of China (General Program, 8127092, 2012) and (General Program, 81471099, 2014) and the Zhejiang Provincial Natural Science Foundation of China (Y17H070002, 2016)

\section{Author contribution statement}

Fenping Zheng and Hong $\mathrm{Li}$ conceived and designed the experiments; Yueting Dong, Zhiye Xu, Ziyi Zhang, Xueyao Yin and Xihua Lin performed the experiments; Fenping Zheng analysed the data and wrote the paper.

\section{References}

Abranches MV, Oliveira FC, Conceicao LL \& Peluzio MD 2015 Obesity and diabetes: the link between adipose tissue dysfunction and glucose homeostasis. Nutrition Research Reviews 28 121-132. (doi:10.1017/S0954422415000098)

Alkhouri N, Gornicka A, Berk MP, Thapaliya S, Dixon LJ, Kashyap S, Schauer PR \& Feldstein AE 2010 Adipocyte apoptosis, a link between obesity, insulin resistance, and hepatic steatosis. Journal of Biological Chemistry 285 3428-3438. (doi:10.1074/jbc.M109.074252)

Archer A, Stolarczyk E, Doria ML, Helguero L, Domingues R, Howard JK, Mode A, Korach-Andre M \& Gustafsson JA 2013 LXR activation by GW3965 alters fat tissue distribution and adipose tissue inflammation in ob/ob female mice. Journal of Lipid Research $\mathbf{5 4}$ 1300-1311. (doi:10.1194/jlr.M033977)

Baranowski M 2008 Biological role of liver X receptors. Journal of Physiology and Pharmacology 59 (Supplement 7) 31-55.

Beaven SW, Matveyenko A, Wroblewski K, Chao L, Wilpitz D, Hsu TW, Lentz J, Drew B, Hevener AL \& Tontonoz P 2013 Reciprocal regulation of hepatic and adipose lipogenesis by liver $\mathrm{X}$ receptors in obesity and insulin resistance. Cell Metabolism 18 106-117. (doi:10.1016/j.cmet.2013.04.021)

Bennett G, Strissel KJ, DeFuria J, Wang J, Wu D, Burkly LC \& Obin MS 2014 Deletion of TNF-like weak inducer of apoptosis (TWEAK) protects mice from adipose and systemic impacts of severe obesity. Obesity 22 1485-1494. (doi:10.1002/oby.20726)

Cao G, Liang Y, Broderick CL, Oldham BA, Beyer TP, Schmidt RJ, Zhang Y, Stayrook KR, Suen C, Otto KA, et al. 2003 Antidiabetic action of a liver $\mathrm{x}$ receptor agonist mediated by inhibition of hepatic gluconeogenesis. Journal of Biological Chemistry 278 1131-1136. (doi:10.1074/jbc.M210208200)

Cha JY \& Repa JJ 2007 The liver X receptor (LXR) and hepatic lipogenesis. The carbohydrate-response element-binding protein is a target gene of LXR. Journal of Biological Chemistry 282 743-751. (doi:10.1074/jbc.M605023200)

Chen J, Cui X, Zacharek A, Roberts C \& Chopp M 2009 eNOS mediates TO90317 treatment-induced angiogenesis and functional outcome after stroke in mice. Stroke 40 2532-2538. (doi:10.1161/ STROKEAHA.108.545095)

Chisholm JW, Hong J, Mills SA \& Lawn RM 2003 The LXR ligand T0901317 induces severe lipogenesis in the $\mathrm{db} / \mathrm{db}$ diabetic mouse. Journal of Lipid Research 44 2039-2048. (doi:10.1194/jlr.M300135JLR200)

Choi SM, Tucker DF, Gross DN, Easton RM, DiPilato LM, Dean AS, Monks BR \& Birnbaum MJ 2010 Insulin regulates adipocyte lipolysis

Published by Bioscientifica Ltd. 
via an Akt-independent signaling pathway. Molecular and Cellular Biology 30 5009-5020. (doi:10.1128/MCB.00797-10)

Cock TA, Houten SM \& Auwerx J 2004 Peroxisome proliferator-activated receptor-gamma: too much of a good thing causes harm. EMBO Reports 5 142-147. (doi:10.1038/sj.embor.7400082)

Commerford SR, Vargas L, Dorfman SE, Mitro N, Rocheford EC, Mak PA, Li X, Kennedy P, Mullarkey TL \& Saez E 2007 Dissection of the insulin-sensitizing effect of liver X receptor ligands. Molecular Endocrinology 21 3002-3012. (doi:10.1210/me.2007-0156)

Derosa G \& Maffioli P 2012 Peroxisome proliferator-activated receptorgamma (PPAR-gamma) agonists on glycemic control, lipid profile and cardiovascular risk. Current Molecular Pharmacology 5 272-281. (doi:10.2174/1874467211205020272)

Despres JP \& Lemieux I 2006 Abdominal obesity and metabolic syndrome. Nature 444 881-887. (doi:10.1038/nature05488)

Dib L, Bugge A \& Collins S 2014 LXRalpha fuels fatty acid-stimulated oxygen consumption in white adipocytes. Journal of Lipid Research 55 247-257. (doi:10.1194/jlr.M043422)

Garg A 2011 Clinical review\#: lipodystrophies: genetic and acquired body fat disorders. Journal of Clinical Endocrinology and Metabolism 96 3313-3325. (doi:10.1210/jc.2011-1159)

Hijmans BS, Tiemann CA, Grefhorst A, Boesjes M, van Dijk TH, Tietge UJ, Kuipers F, van Riel NA, Groen AK \& Oosterveer MH 2015 A systems biology approach reveals the physiological origin of hepatic steatosis induced by liver $\mathrm{X}$ receptor activation. FASEB Journal 29 1153-1164. (doi:10.1096/fj.14-254656)

Hirsch J \& Han PW 1969 Cellularity of rat adipose tissue: effects of growth, starvation, and obesity. Journal of Lipid Research 10 77-82.

Hummasti S, Laffitte BA, Watson MA, Galardi C, Chao LC, Ramamurthy L, Moore JT \& Tontonoz P 2004 Liver X receptors are regulators of adipocyte gene expression but not differentiation: identification of apoD as a direct target. Journal of Lipid Research 45 616-625. (doi:10.1194/jlr.M300312-JLR200)

Ide T, Shimano H, Yoshikawa T, Yahagi N, Amemiya-Kudo M, Matsuzaka T, Nakakuki M, Yatoh S, Iizuka Y, Tomita S, et al. 2003 Cross-talk between peroxisome proliferator-activated receptor (PPAR) alpha and liver X receptor (LXR) in nutritional regulation of fatty acid metabolism. II. LXRs suppress lipid degradation gene promoters through inhibition of PPAR signaling. Molecular Endocrinology $\mathbf{1 7}$ 1255-1267. (doi:10.1210/me.2002-0191)

Jankovic A, Korac A, Buzadzic B, Otasevic V, Stancic A, Daiber A \& Korac B 2015 Redox implications in adipose tissue (dys)function-A new look at old acquaintances. Redox Biology 6 19-32. (doi:10.1016/j. redox.2015.06.018)

Juvet LK, Andresen SM, Schuster GU, Dalen KT, Tobin KA, Hollung K, Haugen F, Jacinto S, Ulven SM, Bamberg K, et al. 2003 On the role of liver $\mathrm{X}$ receptors in lipid accumulation in adipocytes. Molecular Endocrinology 17 172-182. (doi:10.1210/me.2001-0210)

Kalaany NY, Gauthier KC, Zavacki AM, Mammen PP, Kitazume T, Peterson JA, Horton JD, Garry DJ, Bianco AC \& Mangelsdorf DJ 2005 LXRs regulate the balance between fat storage and oxidation. Cell Metabolism 1 231-244. (doi:10.1016/j.cmet.2005.03.001)

Korach-Andre M, Archer A, Gabbi C, Barros RP, Pedrelli M, Steffensen KR, Pettersson AT, Laurencikiene J, Parini P \& Gustafsson JA 2011 Liver $X$ receptors regulate de novo lipogenesis in a tissue-specific manner in C57BL/6 female mice. American Journal of Physiology: Endocrinology and Metabolism 301 E210-E222. doi:10.1152/ajpendo.00541.2010

Laffitte BA, Chao LC, Li J, Walczak R, Hummasti S, Joseph SB, Castrillo A, Wilpitz DC, Mangelsdorf DJ, Collins JL, et al. 2003 Activation of liver $\mathrm{X}$ receptor improves glucose tolerance through coordinate regulation of glucose metabolism in liver and adipose tissue. PNAS 100 5419-5424. (doi:10.1073/pnas.0830671100)

Laurencikiene J \& Ryden M 2012 Liver X receptors and fat cell metabolism. International Journal of Obesity 36 1494-1502. (doi:10.1038/ijo.2012.21)
Lionetti L, Mollica MP, Lombardi A, Cavaliere G, Gifuni G \& Barletta A 2009 From chronic overnutrition to insulin resistance: the role of fat-storing capacity and inflammation. Nutrition, Metabolism and Cardiovascular Diseases 19 146-152. (doi:10.1016/j. numecd.2008.10.010)

Liu Y, Yan C, Wang Y, Nakagawa Y, Nerio N, Anghel A, Lutfy K \& Friedman TC 2006 Liver X receptor agonist T0901317 inhibition of glucocorticoid receptor expression in hepatocytes may contribute to the amelioration of diabetic syndrome in $\mathrm{db} / \mathrm{db}$ mice. Endocrinology 147 5061-5068. (doi:10.1210/en.2006-0243)

Martinez-Botas J, Anderson JB, Tessier D, Lapillonne A, Chang BH, Quast MJ, Gorenstein D, Chen KH \& Chan L 2000 Absence of perilipin results in leanness and reverses obesity in $\operatorname{Lepr}(\mathrm{db} / \mathrm{db})$ mice. Nature Genetics 26 474-479. (doi:10.1038/82630)

Medina-Gomez G, Gray SL, Yetukuri L, Shimomura K, Virtue S, Campbell M, Curtis RK, Jimenez-Linan M, Blount M, Yeo GS, et al. 2007 PPAR gamma 2 prevents lipotoxicity by controlling adipose tissue expandability and peripheral lipid metabolism. PLoS Genetics 3 e64. (doi:10.1371/journal.pgen.0030064)

Miles PD, Barak Y, He W, Evans RM \& Olefsky JM 2000 Improved insulin-sensitivity in mice heterozygous for PPAR-gamma deficiency. Journal of Clinical Investigation 105 287-292. (doi:10.1172/JCI8538)

Mottagui-Tabar S, Ryden M, Lofgren P, Faulds G, Hoffstedt J, Brookes AJ, Andersson I \& Arner P 2003 Evidence for an important role of perilipin in the regulation of human adipocyte lipolysis. Diabetologia 46 789-797. (doi:10.1007/s00125-003-1112-x)

Murdolo G, Bartolini D, Tortoioli C, Piroddi M, Iuliano L \& Galli F 2013 Lipokines and oxysterols: novel adipose-derived lipid hormones linking adipose dysfunction and insulin resistance. Free Radical Biology and Medicine 65 811-820. (doi:10.1016/j.freeradbiomed.2013.08.007)

Nomiyama T \& Bruemmer D 2008 Liver X receptors as therapeutic targets in metabolism and atherosclerosis. Current Atherosclerosis Reports 10 88-95. (doi:10.1007/s11883-008-0013-3)

Pettersson AM, Stenson BM, Lorente-Cebrian S, Andersson DP, Mejhert N, Kratzel J, Astrom G, Dahlman I, Chibalin AV, Arner P, et al. 2013 LXR is a negative regulator of glucose uptake in human adipocytes. Diabetologia 56 2044-2054. (doi:10.1007/s00125013-2954-5)

Romacho T, Elsen M, Rohrborn D \& Eckel J 2014 Adipose tissue and its role in organ crosstalk. Acta Physiologica 210 733-753. (doi:10.1111/ apha.12246)

Roncari DA, Lau DC \& Kindler S 1981 Exaggerated replication in culture of adipocyte precursors from massively obese persons. Metabolism 30 425-427. (doi:10.1016/0026-0495(81)90174-8)

Schultz JR, Tu H, Luk A, Repa JJ, Medina JC, Li L, Schwendner S, Wang S, Thoolen M, Mangelsdorf DJ, et al. 2000 Role of LXRs in control of lipogenesis. Genes and Development 14 2831-2838. (doi:10.1101/gad.850400)

Stenson BM, Ryden M, Steffensen KR, Wahlen K, Pettersson AT, Jocken JW, Arner P \& Laurencikiene J 2009 Activation of liver X receptor regulates substrate oxidation in white adipocytes. Endocrinology 150 4104-4113. (doi:10.1210/en.2009-0676)

Stenson BM, Ryden M, Venteclef N, Dahlman I, Pettersson AM, Mairal A, Astrom G, Blomqvist L, Wang V, Jocken JW, et al. 2011 Liver X receptor (LXR) regulates human adipocyte lipolysis. Journal of Biological Chemistry 286 370-379. (doi:10.1074/jbc.M110.179499)

Tansey JT, Sztalryd C, Gruia-Gray J, Roush DL, Zee JV, Gavrilova O, Reitman ML, Deng CX, Li C, Kimmel AR, et al. 2001 Perilipin ablation results in a lean mouse with aberrant adipocyte lipolysis, enhanced leptin production, and resistance to diet-induced obesity. PNAS 98 6494-6499. (doi:10.1073/pnas.101042998)

Tinahones FJ, Coin Araguez L, Murri M, Oliva Olivera W, Mayas Torres MD, Barbarroja N, Gomez Huelgas R, Malagon MM \& El Bekay R 2013 Caspase induction and BCL2 inhibition in human adipose tissue: a potential relationship with insulin signaling alteration. Diabetes Care 36 513-521. (doi:10.2337/dc12-0194) 
Wang F, Mullican SE, DiSpirito JR, Peed LC \& Lazar MA 2013 Lipoatrophy and severe metabolic disturbance in mice with fatspecific deletion of PPARgamma. PNAS 110 18656-18661. (doi:10.1073/pnas.1314863110)

Yamauchi T \& Kadowaki T 2001 The molecular mechanisms by which PPAR gamma/RXR inhibitors improve insulin resistance. Nihon Rinsho 59 2245-2254.

Yoshikawa T, Ide T, Shimano H, Yahagi N, Amemiya-Kudo M, Matsuzaka T, Yatoh S, Kitamine T, Okazaki H, Tamura Y, et al. 2003 Cross-talk between peroxisome proliferator-activated receptor (PPAR) alpha and liver X receptor (LXR) in nutritional regulation of fatty acid metabolism. I. PPARs suppress sterol regulatory element binding protein-1c promoter through inhibition of LXR signaling. Molecular Endocrinology 17 1240-1254. (doi:10.1210/me.2002-0190)
Yoshikawa T, Shimano H, Amemiya-Kudo M, Yahagi N, Hasty AH Matsuzaka T, Okazaki H, Tamura Y, Iizuka Y, Ohashi K, et al. 2001 Identification of liver $\mathrm{X}$ receptor-retinoid $\mathrm{X}$ receptor as an activator of the sterol regulatory element-binding protein 1c gene promoter. Molecular and Cellular Biology 21 2991-3000. (doi:10.1128/ MCB.21.9.2991-3000.2001)

Zelcer N \& Tontonoz P 2006 Liver X receptors as integrators of metabolic and inflammatory signaling. Journal of Clinical Investigation 116 607-614. (doi:10.1172/JCI27883)

Zheng F, Zhang S, Lu W, Wu F, Yin X, Yu D, Pan Q \& Li H 2014 Regulation of insulin resistance and adiponectin signaling in adipose tissue by liver $\mathrm{X}$ receptor activation highlights a cross-talk with PPARgamma. PLoS ONE 9 e101269. (doi:10.1371/journal. pone.0101269)

Received in final form 26 January 2017

Accepted 30 January 2017 (c) 2017 Society for Endocrinology Printed in Great Britain
Published by Bioscientifica Ltd. 